\title{
The Psychological Resources of Personality-Based Confidentiality: Possibilities of Personality Trust in Oneself and Others
}

\section{Психологічні ресурси особистісної конфіденції: можливості довіри людини до себе й інших}

\author{
Olena Shtepa \\ Ph.D. in Psychology, Assistant Professor, Ivan Franko National \\ University of Lviv, Lviv (Ukraine) \\ ORCID ID: https://orcid.org/0000-0002-5396-3279 \\ Researcher ID: S-9557-2018 \\ E-mail: Olena.Shtepa@lnu.edu.ua
}

\section{Олена Штепа}

Кандидат психологічних наук, доцент, Львівський національний університет імені Івана Франка, м. Львів (Україна)

\section{ABSTRACT}

The aim of the article is to define personality-based confidentiality resources in an empirical way.

The following methods were used: a psychological survey with the use of personality resourceful questionnaire, a psychological resource questionnaire, a test questionnaire for diagnosing indicators of existential resources, a questionnaire for virtues and character strengths, a questionnaire for coping with a crisis, a psychological well-being questionnaire, a coherence scale, methods for determining tolerance to uncertainty, and estimation methods and predicting the development of situations of interpersonal interaction, questionnaire of reflexivity,

Address for correspondence, e-mail: kpnu_lab_ps@ukr.net Copyright: (C) Shtepa Olena

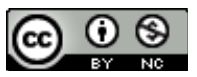

(C) Shtepa Olena 
methods of trust / distrust of a person to the world, others, himself. Methods of mathematical statistical analysis such as Tests of Normality, multivariate analysis, cluster analysis of k-medium method, classification analysis, comparative analysis, discriminant analysis are applied. The empirical study was implemented according to the Nelson's model, since conditions were set for determining the resources of personal confidentiality, namely: the level of human confidence in himself, the level of human confidence in others, the level of system reflection, and the certainty of resource content.

The results of the research. It is proved that a person's search for shortcomings in himself and others is a criterion of his readiness to mistrust both himself and others. The predictors of the embodiment of confidentiality in relation to a person towards himself and others are the psychological resources of working on oneself, responsibility, helping others, realized through resources as "character forces» - openness to new experience, leadership, and ability to forgive, kindness. According to the results of the empirical study, it is leadership as the ability to inspire and organize oneself and others, which is the main factor and predictor of a person's trust in oneself and other people.

Conclusions. The main resources for the embodiment of confidentiality are reflexive resources, which include psychological resources and resources as "character forces». The results of the study give reasons to consider the psychological resources of working on oneself as "recovery resources», (shared) responsibility, kindness to others and helping them who interpret, and, accordingly, make it possible to conceptualize subjective activity, that is, to realize personal self-understanding; as well as "strength of character" as an openness to new experience, leadership, the ability to forgive, kindness, giving the opportunity to argue the understanding.

Key words: psychological resources, personality confidentiality, "recovery resources», a person's trust in himself, a person's trust in others.

\section{Introduction}

Trust as a special confidential type of attitude of the person to the world, oneself, other people is one of the important issues of personality psychology and relationships. At the same time, if classical psychology provides a psychoanalytic explanation of the reasons for (non)trust in the world, as (un) formation of his / her sense of basic (dis) trust in the relation-

DOI (article): https://doi.org/10.32626/2227-6246.2020-50.352-374

(C) Shtepa Olena 
ship with the mother during the first year of his / her life, then in nonclassical psychology the problem of trust is defined according to its purpose and process. In particular, it is shown that modern man's distrust to the metanarrative - a universal, "great story» about transcendent, "pre-established» commandments, which interprets the existential meaning of the world and the existence of the personality in it (Извеков, 2012: 94) causes exhaustion of self-understanding.

Trust is characterized as a «socio-psychological phenomenon of the relationship that arises in the interaction and reflects the internal position of the subject, due to the predicted assessment of the results of this interaction" (Лисенко, 2018: 124). Scholars emphasize that trust is both a condition and a consequence of cooperation (Василець, 2016: 15, 41), which allow to characterize trust as a prerequisite for the social capital of organizations and society (Купрейченко, 2008: 372). According to F. Fukuyama (2004: 22), trust is revealed in people's expectations of predictable and honest behavior towards each other.

Trust as a configuration of confidentiality allows the exchange of information and various resources (Купрейченко, 2008: 369, 373). In particular, in Ostrom's model of trusting relationships (Zanini \& Migueles, 2013: 82) aspects of trust characterize good name, reciprocity, cooperation, and result is in "pure benefit». A. Kupreichenko (Kupreichenko, 2008: 373-374) presents the results of experiments on changing the behavior and level of communication of (distrustful) people, when they are offered competition and cooperation in situations of reducing common resources, which indicated the benefits for the organization of trusting relationships.

Sociologists have proved that the importance of trust is actualized under conditions of uncertainty and becomes a social resource that, in contrast to hopes and faith, is manifested in actions (Общество без доверия, 2014: 15, 16, 54). Psychologists have clarified that this social resource of interaction is (c) Shtepa Olena

DOI (article): https://doi.org/10.32626/2227-6246.2020-50.352-374 
an accumulated successful experience of social interaction, which, in turn, becomes a buffer about uncertainty in times of social upheaval (Купрейченко, 2008: 68). At the same time, researchers have noted that social frustrations in the modern world are post-truth overcome in the way of presenting «truthlight» (Саноцька, 2017: 108), which does not contribute to the formation of personal experience of (dis)trust in the world. Thus, the lack / falsity of experience of (dis)trust complicates the possibility of interpretation of self and personal life situation, and, according to researchers, interpretation is a way of self-determination and affirmation of the subjective position of the person (Самопроектування особистості..., 2016: 6; Пушкарев, 2012: 20).

The consequences of lack of grounds for trust include the following: reduction of trust potential as a psychotherapeutic «recovery resource» of the individual (Шевченко, 2015: 276), lack of self-confidence complicates trust in others (Крива, 2018: 131), lack of trust in others causes stagnation of personal development (Купрейченко, 2008: 76), the loss of confidential about the metanarrative makes it impossible to interpreted and understand a person for himself (Извеков, 2012: 94).

The problem of sufficient grounds for (dis) trust, in our opinion, is that a person can find opportunities for confidential, even in the absence of grounds. In our opinion, personal confidentiality is a dynamic state-experience of a person-initiated comparison of one's own expectations about oneself and other people with a metanarrative, because trust is realized in an act which, according to V. Roments, is a consequence of moral self-determination (M'ясоїд, 2016: 55). Probably, the result of this comparison is a person's sense of self intention. We consider the possibilities of personal confidentiality to establish, actualize as a person's ability of interpretation of himself in the context of the life situation in relation to the metanarrative.

(C) Shtepa Olena

DOI (article): https://doi.org/10.32626/2227-6246.2020-50.352-374 
DOI: https://doi.org/10.32626/2227-6246.2020-50 2020. ВипУСК 50

We consider psychological resources to be the means of this interpretation because scientists characterize resources as mechanisms that allow them to regulate their own activity in a way of conceptualization (Хазова, 2014: 117); means, (in) sufficiency of which determines the level of psychological wellbeing (Иванова et al., 2018: 87); existential-cognitive codes of human interpretation of the significance of event (Штепа, 2019b: 92). The fact that psychological resources make it possible to correspond with a metanarrative has been proved in the researches on the connection between psychological resources and idealism, but not relativism (Штепа, 2019a: 437).

Solving the problem of resources of the personality-based confidential will make it possible to concretize the motivational psychotherapeutic metaphor of «recovery resources» and will make it possible to more clearly outline the ways of conceptualizing subjective activity under conditions of uncertainty.

The aim of the study was to find out the resources of personality-based confidentiality in an empirical way.

\section{The task of the article}

The objectives of the article are as follows:

1) to determine the psychological resources of personality-based confidentiality empirically in themselves and others;

2) to interpret the functions of psychological resources of personality-based confidentiality.

\section{Methods of research}

The empirical study was implemented according to Nelson's model, because the conditions for determining the resources of personality-based confidentiality were set, namely: the level of personal confidence in oneself, the level of personal confidence in others, the level of system reflection, and certainty of the content of resource richness. Empirically, personal confidentiality was diagnosed using the author's method of trust / distrust of the individual of the world, other people, himself (c) Shtepa Olena

DOI (article): https://doi.org/10.32626/2227-6246.2020-50.352-374 
(Купрейченко, 2011: 11-12); to determine the systemic reflection as a criterion for awareness of actualized resources we used a questionnaire of reflection by D. Leotiev, E. Osin. The bases of the certainty of resource content were the results of a study on the components of resource richness (Штепа, 2020: 236). Since the phenomenon of trust characterizes a person's attitude to himself and others as a process, it has become possible to use the context of the phenomenon of confidentiality to interpret the functions of psychological resources.

The study involved 420 people aged 21-67 years $(\mathrm{M}=42.3)$ (including $57 \%$ women, $43 \%$ men) (4-6-year students and teachers of educational institutions of 3-4 degrees, students of the Institute of Pre-University and Postgraduate Education, students of Lviv "University of the Third Age», private entrepreneurs of small business).

\section{Results and discussions}

To determine the predicted reliability of the empirical model of personal confidentiality resources to indicators of (non) trust to oneself and others, the Tests of Normality were applied, which showed that the Kolmogorov-Smirnov's Test has $\mathrm{p}<\mathbf{0 . 0 1}$ for scales of the confidence of a person in himself and others "expectations of reliability", "expectation of unity", «expectation of knowledge», «expectation of friendliness», "expectation of calculation", "expectation of shortcomings in others»; for scales «expectation of shortcomings in oneself», «general level of self-confidence», "general level of confidence to others» $-p<0.05$; the indicator of Lilliefors test for all scales is $\mathrm{p}<0.01$; the Shapiro-Wilk test for all scales ranges from 0.89 to 0.98 .

To determine the awareness of actualized resources of personality-based confidentiality, a discriminant analysis was used, which by the value of the indicator of Wilks' Lambda (0.82) showed that the conscious, self-regulating components of resource content of the confidence of oneself and others are:

(C) Shtepa Olena

DOI (article): https://doi.org/10.32626/2227-6246.2020-50.352-374 
psychological resources to help others, responsibility, work on oneself; "strengths of character» flexibility of thinking, leadership, sensitivity, the ability to forgive.

In order to determine the components of the empirical model of (dis) trust in oneself and others, discriminant analysis was used (Table 1, Table 2).

Table 1

Resource components of the discriminant model of (dis)trust of a person to himself (8 components, Wilks' Lambda (0.91))

\begin{tabular}{|c|c|c|c|c|c|c|}
\hline $\begin{array}{l}\text { Psychological } \\
\text { resources }\end{array}$ & 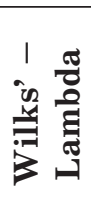 & 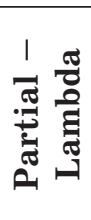 & 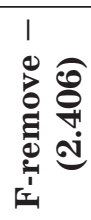 & $\frac{\vec{d}}{0}$ & $\stackrel{\dot{0}}{\stackrel{0}{0}}$ & 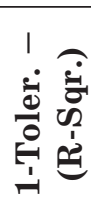 \\
\hline $\begin{array}{l}\text { "Strength of character» } \\
\text { leadership }\end{array}$ & 0.92 & 0.98 & 3.04 & 0.04 & 0.79 & 0.20 \\
\hline \begin{tabular}{|l|} 
Psychological resource \\
«work on oneself»
\end{tabular} & 0.92 & 0.98 & 2.54 & 0.07 & 0.66 & 0.33 \\
\hline $\begin{array}{l}\text { «Strength of character» } \\
\text { prudence }\end{array}$ & 0.92 & 0.98 & 3.36 & 0.03 & 0.83 & 0.16 \\
\hline $\begin{array}{l}\text { «Strength of character» } \\
\text { sense of beauty }\end{array}$ & 0.92 & 0.98 & 2.82 & 0.06 & 0.92 & 0.07 \\
\hline $\begin{array}{l}\text { Psychological resource } \\
\text { of «confidence» }\end{array}$ & 0.92 & 0.98 & 2.77 & 0.06 & 0.83 & 0.16 \\
\hline $\begin{array}{l}\text { Psychological resource } \\
\text { of «responsibility» }\end{array}$ & 0.92 & 0.98 & 3.20 & 0.04 & 0.59 & 0.40 \\
\hline $\begin{array}{l}\text { Psychological resource } \\
\text { of «kindness to people» }\end{array}$ & 0.91 & 0.99 & 1.57 & 0.20 & 0.58 & 0.41 \\
\hline $\begin{array}{l}\text { «Strength of character» } \\
\text { frankness }\end{array}$ & 0.91 & 0.99 & 1.36 & 0.25 & 0.95 & 0.04 \\
\hline
\end{tabular}

The results of empirical discrimination showed that the resource components of (dis)trust of a person to oneself and others are the psychological resources of interpretive and sig(C) Shtepa Olena

DOI (article): https://doi.org/10.32626/2227-6246.2020-50.352-374 
nificant functions, as well as «strength of character», which specify the ways of realization of values. Thus, (non)trust of a person to oneself and others is defined and interpreted through a sense of one's own ability to reflexive self-change, including overcoming fear of life, as well as through a sense of self-confidence as the ability to make decisions, and responsibility as the ability to predict the consequences of one's actions. The importance of self-change and self-confidence is realized through openness, prudence, the ability to inspire.

The resource components of (non)trust of a person to oneself and others are psychological resources, «strength of character", the resource of tolerance to uncertainty, the resource of relationships, the resources of psychological survival (Table 2).

The results of discriminant analysis made it possible to clarify that (non)trust of a person to oneself and other people is defined and interpreted through opportunities for cooperation, tolerance, self-change, as well as, in fact, knowledge of whether he is able to be tolerant and cooperate with them. The importance of self-knowledge and self-change is realized through leadership, openness to new experiences, interest in others, sensitivity, openness, the ability to forgive. In order to have sufficient grounds for (non)trust in others, resources of tolerance to uncertainty are needed, which create a buffer for life stress, in particular for novelty; resources of psychological survival (have the function of transforming psychological obstacles into opportunities) - the ability to rely on their own beliefs and convictions, as well as a sense of physical comfort; among the resources of relationships that perform a discursive function, the component of material contribution turned out to be important.

It is worth noting, that the generic resources of (non)trust in oneself and others in the discriminatory models are the psychological resource of working on oneself and such «forces of character» as leadership and openness.

(C) Shtepa Olena

DOI (article): https://doi.org/10.32626/2227-6246.2020-50.352-374 
Resource components of the discriminant model of (non)trust of a person to others (13 components, Wilks’ Lambda (0.86))

\begin{tabular}{|c|c|c|c|c|c|c|}
\hline $\begin{array}{l}\text { Psychological } \\
\text { resources }\end{array}$ & 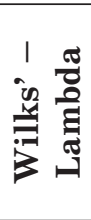 & 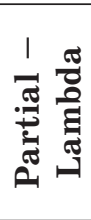 & 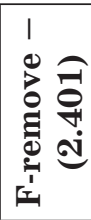 & $\frac{\vec{d}}{d_{0}}$ & $\underset{\dot{d}}{\stackrel{\dot{\sigma}}{0}}$ & 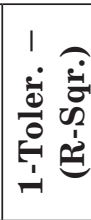 \\
\hline $\begin{array}{l}\text { Psychological resource } \\
\text { «helping others» }\end{array}$ & 0.86 & 0.99 & 1.66 & 0.19 & 0.58 & 0.41 \\
\hline \begin{tabular}{|l|} 
Psychological resource \\
«knowledge of own resources»
\end{tabular} & 0.86 & 0.99 & 1.94 & 0.14 & 0.58 & 0.41 \\
\hline $\begin{array}{l}\text { Resource of tolerance } \\
\text { to uncertainty «novelty» }\end{array}$ & 0.86 & 0.99 & 1.46 & 0.23 & 0.92 & 0.07 \\
\hline $\begin{array}{l}\text { «Strength of character» } \\
\text { leadership }\end{array}$ & 0.87 & 0.98 & 3.48 & 0.03 & 0.71 & 0.28 \\
\hline $\begin{array}{l}\text { «Strength of character» } \\
\text { flexibility of thinking }\end{array}$ & 0.86 & 0.98 & 2.45 & 0.08 & 0.74 & 0.25 \\
\hline $\begin{array}{l}\text { Psychological resource } \\
\text { «work on oneself» }\end{array}$ & 0.86 & 0.98 & 2.42 & 0.08 & 0.76 & .23 \\
\hline $\begin{array}{l}\text { «Strength of character» } \\
\text { curiosity }\end{array}$ & 0.87 & 0.98 & 3.60 & 0.02 & 0.77 & 0.22 \\
\hline $\begin{array}{l}\text { Resource of psychological } \\
\text { survival «physical activity» }\end{array}$ & 0.87 & 0.98 & 2.86 & 0.05 & 0.31 & 0.68 \\
\hline $\begin{array}{l}\text { Resource of psychological } \\
\text { survival «faith» }\end{array}$ & 0.86 & 0.98 & 2.46 & 0.08 & 0.48 & 0.51 \\
\hline $\begin{array}{l}\text { «Strength of character» } \\
\text { sensitivity }\end{array}$ & 0.86 & 0.99 & 1.43 & 0.23 & 0.59 & 0.40 \\
\hline $\begin{array}{l}\text { «Strength of character» } \\
\text { frankness }\end{array}$ & 0.86 & 0.99 & 1.82 & 0.16 & 0.77 & 0.22 \\
\hline $\begin{array}{l}\text { Resource of the relationship } \\
\text { «material contribution» }\end{array}$ & 0.86 & 0.99 & 1.16 & 0.31 & 0.79 & 0.20 \\
\hline $\begin{array}{l}\text { «Strength of character» } \\
\text { the ability to forgive }\end{array}$ & 0.86 & 0.99 & 1.02 & 0.36 & 0.605 & 0.39 \\
\hline
\end{tabular}

(C) Shtepa Olena

DOI (article): https://doi.org/10.32626/2227-6246.2020-50.352-374 
In order to establish the structure of opportunities for (non)trust in oneself and others, a multifactor analysis was applied, which included psychological resources of (non)trust in oneself, psychological resources of (non)trust in others, previously discriminated against current indicators of (non)trust in oneself and others. As a result of two iterations, the completed empirical five-factor model of psychological resources of (non)trust in oneself and others characterized $76.2 \%$ of the variance (Table 3$)$.

Table 3

The results of multifactor analysis of the psychological resources of confidentiality (factor weight $>0.7$ )

\begin{tabular}{|c|c|c|c|c|c|}
\hline $\begin{array}{c}\text { Components and } \\
\text { psychological resources } \\
\text { of (non)trust in oneself } \\
\text { and others }\end{array}$ & $\mid \begin{array}{c}\text { Fac- } \\
\text { tor 1 } \\
(23.6 \%)\end{array}$ & $\mid \begin{array}{c}\text { Fac- } \\
\text { tor } 2 \\
(14.1 \%)\end{array}$ & $\begin{array}{c}\text { Fac- } \\
\text { tor } 3 \\
(13.0 \%)\end{array}$ & $\begin{array}{c}\text { Fac- } \\
\text { tor } 4 \\
(10.1 \%)\end{array}$ & $\begin{array}{c}\text { Fac- } \\
\text { tor 5 } \\
(9.4 \%)\end{array}$ \\
\hline $\begin{array}{l}\text { Psychological resource } \\
\text { «kindness to people» }\end{array}$ & 0.85 & 0.10 & -0.16 & 0.04 & 0.057 \\
\hline $\begin{array}{l}\text { Psychological resource } \\
\text { «helping others» }\end{array}$ & 0.75 & 0.11 & 0.14 & 0.16 & -0.11 \\
\hline $\begin{array}{l}\text { Psychological resource } \\
\text { «work on oneself» }\end{array}$ & 0.68 & -0.01 & 0.04 & 0.01 & 0.25 \\
\hline $\begin{array}{l}\text { Psychological resource } \\
\text { «responsibility» }\end{array}$ & 0.79 & 0.03 & 0.12 & 0.15 & 0.02 \\
\hline $\begin{array}{l}\text { «Strength of character» } \\
\text { flexibility of thinking }\end{array}$ & 0.03 & 0.05 & 0.14 & 0.07 & 0.78 \\
\hline $\begin{array}{l}\text { «Strength of character» } \\
\text { sensitivity }\end{array}$ & 0.04 & 0.01 & 0.86 & 0.01 & 0.09 \\
\hline $\begin{array}{l}\text { «Strength of character» } \\
\text { leadership }\end{array}$ & 0.10 & 0.05 & 0.01 & -0.03 & 0.85 \\
\hline $\begin{array}{l}\text { "Strength of character» } \\
\text { the ability to forgive }\end{array}$ & 0.06 & 0.01 & 0.86 & -0.05 & 0.06 \\
\hline $\begin{array}{l}\text { The component of (non) } \\
\text { trust: the expectation of } \\
\text { shortcomings in themselves }\end{array}$ & -0.26 & -0.09 & -0.08 & -0.83 & 0.07 \\
\hline
\end{tabular}

(C) Shtepa Olena 
DOI: https://doi.org/10.32626/2227-6246.2020-50

2020. випуск 50

\begin{tabular}{|l|l|l|l|l|l|}
\hline $\begin{array}{l}\text { The component of (non)trust } \\
\text { in others: expectations of } \\
\text { the reliability of others }\end{array}$ & 0.03 & 0.81 & -0.01 & 0.03 & 0.06 \\
\hline $\begin{array}{l}\text { The component of (non)trust } \\
\text { in others: the expectation } \\
\text { of knowledge of others }\end{array}$ & 0.07 & 0.76 & 0.03 & -0.01 & 0.03 \\
\hline $\begin{array}{l}\text { The component of (non)trust } \\
\text { in others: the expectation } \\
\text { of the calculation of others }\end{array}$ & 0.08 & 0.85 & 0.01 & 0.03 & 0.05 \\
\hline $\begin{array}{l}\text { The component of (non)trust } \\
\text { in others: the expectation } \\
\text { of shortcomings in others }\end{array}$ & -0.04 & 0.01 & 0.11 & -0.89 & -0.08 \\
\hline
\end{tabular}

The results of multifactor analysis showed that psychological resources, which, in our opinion, perform a significant and interpretive function, are crucial for characterizing the phenomenon of trust. Such results, in general, were expected, because a person's attitude to himself and others involves identifying expectations and interpreting events. The second component of resources of (non)trust of a person to himself and others is revealed as «forces of character», through which the values of a person are realized. Our attention, was drawn to the fact that the expectation of shortcomings is important both in (non)trust in oneself and in others, so it was decided to determine the types of (non)trust in oneself and others using cluster analysis by k-means (Fig. 1 - Symbols: Cluster 1: people with a high general level of trust in themselves and others. Cluster 2: individuals with low overall confidence in themselves and others).

According to the cluster analysis, it was found, that the terminator of (non)trust of a person to himself and others, is advisable to determine search for shortcomings in himself and others. In order to clarify this assumption, we implemented a regression analysis of the factors of the general level of (dis) trust in oneself and others (Table 4).

(C) Shtepa Olena

DOI (article): https://doi.org/10.32626/2227-6246.2020-50.352-374 
Plot of Means for Each Cluster

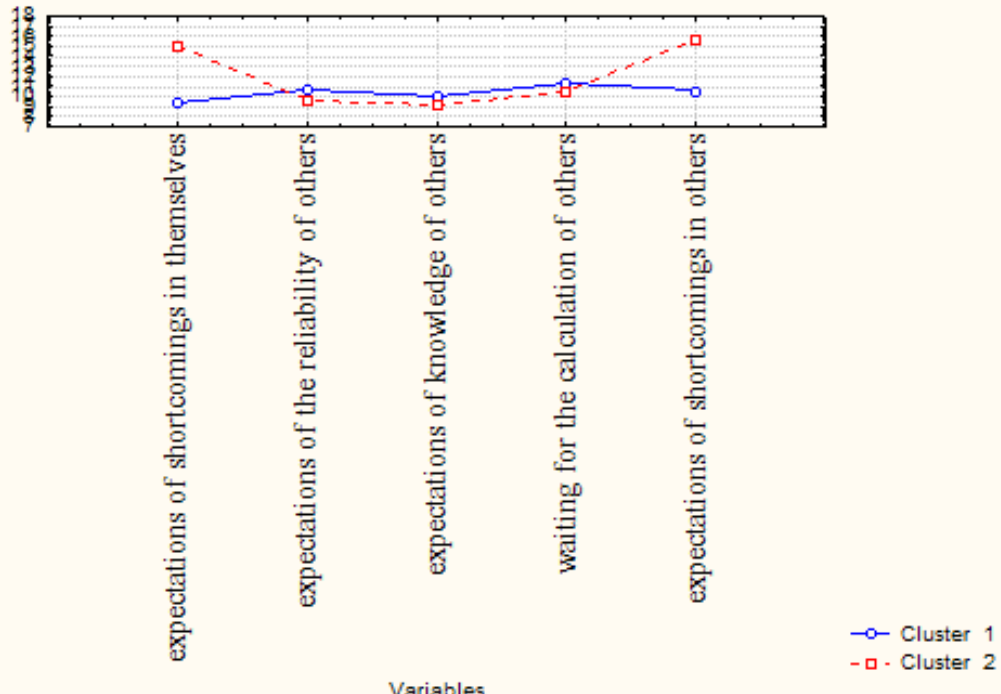

Fig. 1. Types of (non)trust in oneself and others

Table 4

The results of regression analysis of general level factors of personality trust in himself and others

\begin{tabular}{|l|c|c|c|c|c|c|}
\hline $\begin{array}{c}\text { Factors of the general } \\
\text { level of (dis)trust } \\
\text { of a person to himself } \\
\text { and others }\end{array}$ & Beta & $\begin{array}{c}\text { Std. } \\
\text { Err. - } \\
\text { of Beta }\end{array}$ & B & $\begin{array}{c}\text { Std. } \\
\text { Err. } \\
\text { of B }\end{array}$ & $\mathbf{t ( 4 0 9 )}$ & $\begin{array}{c}\text { p-le- } \\
\text { vel }\end{array}$ \\
\cline { 2 - 7 } & & & 62.46 & 3.02 & 20.68 & 0.00 \\
\hline $\begin{array}{l}\text { «Strength of character» } \\
\text { leadership ** }\end{array}$ & 0.15 & 0.04 & 0.53 & 0.17 & 3.13 & 0.00 \\
$\begin{array}{l}\text { Psychological resource } \\
\text { «help to others»* }\end{array}$ & 0.13 & 0.06 & 0.72 & 0.32 & 2.24 & 0.02 \\
\hline $\begin{array}{l}\text { Psychological resource } \\
\text { «responsibility»* }\end{array}$ & -0.13 & 0.06 & -0.82 & 0.37 & -2.19 & 0.02 \\
\hline $\begin{array}{l}\text { Psychological resource } \\
\text { «kindness to people»* }\end{array}$ & 0.16 & 0.06 & 0.88 & 0.35 & 2.45 & 0.01 \\
\hline
\end{tabular}

$$
*(p<0.05) ; * *(p<0.01) \text {. }
$$

(C) Shtepa Olena 
DOI: https://doi.org/10.32626/2227-6246.2020-50 2020. випуск 50

It is worth noting that the resource of leadership is the most important factor in a person's trust in himself and others. It can be interpreted that the way to increase a person's level of trust in himself and others is to be with others in a way of organizing work and inspiration, a person better understands others, as a result of which his / her expectations become more realistic. It is important to note that a person's expectation of high responsibility as self-confidence and reliance on their own experience negatively affects the level of trust in themselves and others, as the desire to perform tasks alone and in their own vision narrows the horizon of competencies and complicates relationships with others.

Based on the results of cluster analysis by the method of k-means and regression analysis, it can be argued, that a search of the person of the shortcomings in himself and others is a criterion of his / her willingness not to trust oneself and others. Figure 2 contains graphs isolated in the results of multifactor analysis of psychological resources of two types of personality (non)trust in themselves and others.

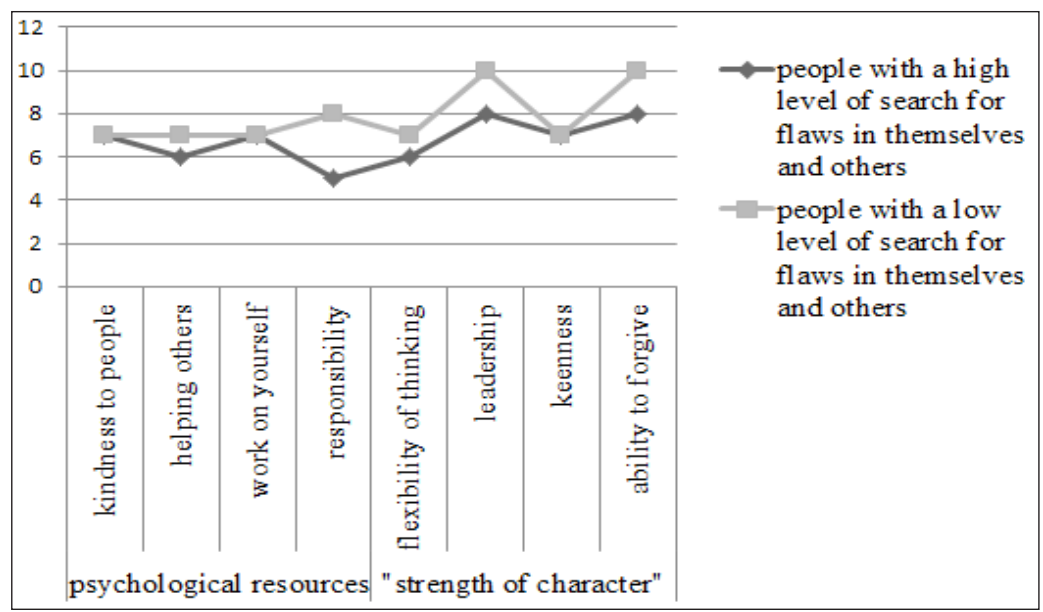

Fig. 2. Graphs of psychological resources of two types of personality (non)trust of themselves and others 
According to the comparative analysis of the Student's t-test, the higher level of psychological responsibility $(p<0.01)$ and «strength of character" leadership $(\mathrm{p}<0.05)$ and the ability to forgive $(\mathrm{p}<0.05)$ should be considered significant, in comparison with the people with a low level of search for flaws in themselves and others. In order to determine the nature of the direction of the psychological resources of the trend of personality's (non)trust in themselves and others, classification analysis (Predictor Variable Rankings method) was used (Table 5).

Table 5

Results of classification analysis of psychological resources of personality confidentiality

\begin{tabular}{|l|l|c|}
\hline \multicolumn{2}{|c|}{$\begin{array}{c}\text { Resource content of personal } \\
\text { confidentiality Predictor rank* }\end{array}$} & $\begin{array}{c}\text { Resource con- } \\
\text { tent of personal } \\
\text { confidentiality } \\
\text { Predictor rank* }\end{array}$ \\
\hline $\begin{array}{l}\text { Psychological resources } \\
\text { Kindness to people }\end{array}$ & $\begin{array}{l}\text { Psychological resources } \\
\text { Kindness to people }\end{array}$ & 48 \\
\cline { 2 - 3 } & Helping others & 62 \\
\cline { 2 - 3 } & Work on yourself & 73 \\
\cline { 2 - 3 } & Responsibility & 80 \\
\hline \multirow{2}{*}{$\begin{array}{l}\text { «Forces of character» } \\
\text { Flexibility of thinking }\end{array}$} & $\begin{array}{l}\text { «Forces of character» } \\
\text { Flexibility of thinking }\end{array}$ & 85 \\
\cline { 2 - 3 } & Keenness & 72 \\
\cline { 2 - 3 } & Leadership & 84 \\
\cline { 2 - 3 } & The ability to forgive & 100 \\
\hline
\end{tabular}

$* 0$ - least important; 100 - the most important.

Data of the analysis of resource's predictors of the general level of trust in oneself and others indicate that leadership, as the ability to inspire and organize, is the mainstream of establishing a trusting relationship between oneself and others. 
DOI: https://doi.org/10.32626/2227-6246.2020-50

2020. випуск 50

Important are the ability to forgive oneself and others, as well as the ability to be open to updating one's own experience. Responsibility as an interpretive resource, largely determines the level of trust in oneself and others, but according to regression analysis, it causes a decrease in trust. It is important to point out that the predictors of confidentiality are reflected by man, in contrast to the resources of relationships, resources of psychological survival, and resources of tolerance to uncertainty. Thus, psychological resources and «strengths of character» can be actualized, and other types of resources can be considered as those that are in the buffer of personal potential.

\section{Conclusions}

The problem of studying the psychological resources of trust was formulated in the possibility modality of the reality of a person's attitude to himself and others, because resources are opportunities, but not given points of expectations. The agonality of the resource discourse of trust is marked by the presence of opportunities for confidentiality in the individual, even in the absence of grounds (i.e. lack of experience, or negative or traumatic experience). In the context of the aggravation of this agonality, we consider the phenomenon of «truthlight», and its settlement - a person's interpretation of his / her own significance and importance of the relationship.

The studies foundout, that a person's search for flaws in himself and others is a criterion of his / her willingness not to trust both himself and others. Predictors of enabling confidentiality are psychological resources of work on oneself, responsibility, help to others, which are realized through resources as "forces of character»- openness to new experiences, leadership, ability to forgive, sensitivity. According to the empirical research, leadership itself as the ability to inspire and organize oneself and others, is the main factor and predictor of personality trust in oneself and others, and leadership as a resource is described as a transsituational quality of personality, which (c) Shtepa Olena

DOI (article): https://doi.org/10.32626/2227-6246.2020-50.352-374 
DOI: https://doi.org/10.32626/2227-6246.2020-50 2020. випуск 50

is able to influence the organization and order concerning others (Peterson \& Seligman, 2004: 416).

Opportunities for personality trust are defined by psychological resources and «strength of character» - responsibility, kindness and help to others, work on oneself, as well as flexibility of thinking, sensitivity, leadership, the ability to forgive. Trust in others still requires the resources of relationships, tolerance of uncertainty, resources of psychological survival, namely: material contributions, tolerance of novelty, the ability to check their own beliefs, physical activity and comfort. The common resources of (non)trust of oneself and others on the discriminatory models are the psychological resource of working on oneself and such «strengths of character» as leadership and openness.

In the context of trust, the functions of psychological resources can be defined as, first of all, as an interpretive and significant. The argumentative function, in our opinion, is performed by «strengths of character» as ways of concretization and realization of values (Peterson \& Seligman, 2004: 392). The role of relationship resources, tolerance to uncertainty, resources of psychological survival, respectively, we consider to be the discursive, buffer (Иванова et al., 2018: 88), and transformative one. Since a person's attitude to himself and others are vectors of his / her personal orientation, we assume that defined functions of psychological resources can be extrapolated beyond the phenomenon of trust and fix as functions of certain types of psychological resources of the individual.

According to the results of the study, the main resources for enabling confidentiality are reflected resources, which include psychological resources and resources as «forces of character». Thus, there are grounds to define "healing resources» as psychological resources of work on oneself, (shared) responsibility, kindness to others and help to them that interpret, and thus allow to conceptualize the subject activity, i.e. they

(c) Shtepa Olena

DOI (article): https://doi.org/10.32626/2227-6246.2020-50.352-374 
DOI: https://doi.org/10.32626/2227-6246.2020-50 2020. випуск 50

allow self-understanding of the individual; as well as such «forces of character» as openness to new experiences, leadership, the ability to forgive, sensitivity, which allow to argue the acquired understanding. The results of the study are quite motivating for re-analysis of the phenomenon of psychological resources in the context of cognitive psychology and psychology of being.

\section{Literature}

Василець Н. М. Соціально-психологічні чинники довіри громадян до працівників органів внутрішніх справ України: дис. ... канд. психол. наук: 19.00.05. Київ : Інститут психології імені Г. С. Костюка, 2016. 523 c. URL : https://ib.iitta.gov.ua/107195/3/Дисертація $\%$ 20Василець.pdf.

Иванова Т., Леонтьев Д., Осин Е., Рассказова Е., Кошелева Н. Современные проблемы изучения личностных ресурсов в профессиональной деятельности. Организационная психология. 2018. Т. 8. № 1. C. 85-121. URL : https://www.orgpsyjournal.hse.ru.

Извеков А. И. Рождение личности постмодерна в кризисе культуры. Исторические, философские, политические и юридические науки, культурология, искусствоведение. Вопросы теории и практики. 2012. № 9 (23). Ч. 1. С. $92-95$.

Крива Н. Л. Проблема довіри в сучасній психології. Теорія $і$ практика сучасної психологї̈. 2018. № 5. С. 128-132.

Купрейченко А. Б. Психология доверия и недоверия. Москва : Изд-во «Институт психологии РАН», 2008. 564 с.

Купрейченко, А. Б. Психология доверия и недоверия личности рекламе. Практична психологія та соиіальна робота. 2011. № 11. C. $5-15$.

Лисенко Д. П. Довіра як соціально-психологічний феномен. Теорія $i$ практика сучасної психологї. 2018. № 3. С. 123-126.

М'ясоїд П. Творчість В. А. Роменця і проблема людини у психології. Психологія і суспільство. 2016. № 2. С. 48-72.

Общество без доверия / под ред. Е. Головахи, Н. Костенко, С. Макеева. Киев : Институт социологии НАН Украины, 2014. 338 с.

Пушкарев Ю. И. Личность как субъект адаптации и субъект интерпретации: системно-герменевтический подход к изучению личности: монография. Белгород : ИД «Белгород», 2012. 209 с.

Самопроектування особистості у дискурсивному просторі: монографія / Н. В. Чепелєва, М. Л. Смульсон, О. В. Зазимко, С. Ю. Гуцол [та (c) Shtepa Olena

DOI (article): https://doi.org/10.32626/2227-6246.2020-50.352-374 http://journals.uran.ua/index.php/2227-6246 
ін.]; за ред. Н. В. Чепелєвої. Київ : Педагогічна думка, 2016. 232 c.

Саноцька, Н. Я. Контури постправди в інформаційному суспільстві. Актуальні проблели філософії та соціологї. 2017. С. 108-111.

Фукуяма Ф. Доверие: социальные добродетели и путь к процветанию / пер. с англ. Москва : ООО «Издательство АСТ»; ЗАО НПП «Ермак», 2004. 730 c. URL : http://yanko.lib.ru.

Хазова С. А. Ментальные ресурсы субъекта в разные возрастные периоды: дис. ... д-ра психол. наук: 19.00.13. Кострома : Костромской государственный университет имени Н. А. Некрасова, 2014. 540 c. URL : https://cyberleninka.ru/article/n/mentalnye-resursysubekta-priroda-funktsii-dinamika.

Шевченко С. В. Сучасні уявлення про феномен довіри до себе. Вісник післядиплолної освіти. 2015. Вип. 15. С. 264-275. URL : http:// nbuv.gov.ua/UJRN/Vpo_2015_15_26.

Штепа О. С. (а) Значення психологічних ресурсів в актуалізації смислових конструктів. Проблели сучасної психології: Зб. наук. пращь Кам'янець-Подільського національного університету ілені Івана Огієнка, Інституту психологї ілені Г. С. Костюка НАПН України / за наук. ред. С. Д. Максименка, Л. А. Онуфрієвої. Кам'янець-Подільський : Аксіома, 2019. Вип. 45. С. 429-450. DOI 10.32626/2227-6246.2019-45.429-450.

Штепа О. С. (б) Ресурсна та мотиваційна актуалізація чуття самоефективності. Здоров'я у мультидисииплінарнолу дискурсі: Матеріали Міжнародної науково-практичної конферениї (м. Львів, 11-13 квітня 2019 р.). Львів : Український католицький університет, 2019. С. 91-94.

Штепа О. С. Ресурсна насиченість особистості. Проблели сучасної психології: Зб. наук. праць Кам'янець-Подільського національного університету ілені Івана Огієнка, Інституту психології ілені Г. С. Костюка НАПН України / за наук. ред. С. Д. Максименка, Л. А. Онуфрієвої. Кам'янець-Подільський : ТОВ «Друкарня «Рута», 2020. Вип. 47. С. 231-252. DOI 10.32626/2227-6246.202047.231-252.

Peterson, C., \& Seligman, M. (2004). Character Strengths and Virtues. A Handbook and Classification. OXFORD UNIVERSITY PRESS. 815 p. URL : http://ldysinger.stjohnsem.edu/\% 40books1/Peterson_ Character_Strengths/character-strengths-and-virtues.pdf.

Zanini, M., \& Migueles, C. (2013). Trust as an element of informal coordination and its relationshipwith organizational performance. EconomiA. № 14. P. 77-87. URL : http://dx.doi.org/10.1016/j.econ. 2013.08.005.

(C) Shtepa Olena

DOI (article): https://doi.org/10.32626/2227-6246.2020-50.352-374 


\section{References}

Vasylets, N. M. (2016). Sotsialno-psykholohichni chynnyky doviry hromadian do pratsivnykiv orhaniv vnutrishnikh sprav Ukrainy [Sociopsychological factors of citizens' trust in employees of internal affairs bodies of Ukraine]. Candidate's thesis. Kyiv : Instytut psykholohii imeni G. S. Kostiuka. Retrieved from https://ib.iitta.gov.ua/ 107195/3/Дисертація\% 20Василець.pdf [in Ukrainian].

Ivanova, T., Leontiev, D., Osin, E., Rasskazova, E., \& Kosheleva, N. (2018). Sovremennyie problemy izucheniia lichnostnykh resursov $\mathrm{v}$ professionalnoi deiatelnosti [Modern problems of the studying of personal's resources in professional activities]. Organizatsionnaia psikhologiia - Organizational psychology, 8 (1), 85-121. Retrieved from https://www.orgpsyjournal.hse.ru [in Russian].

Извеков, А. И. (2012). Rozhdeniie lichnosti postmoderna v krizise kultury [The birth of a postmodern personality in a cultural crisis]. Istoricheskiie, filosofskiie, politicheskiie i yuridicheskiie nauki, kulturologiia, iskusstvovedeniie. Voprosy teorii i praktiki - Historical, philosophical, political and legal sciences, cultural studies, art history. Questions of theory and practice, 9 (23), Ch. 1, 92-95 [in Russian].

Kryva, N. L. (2018). Problema doviry v suchasnii psykholohii [The problem of trust in modern psychology]. Teoriia i praktyka suchasnoi psykholohii - Theory and practice of modern psychology, 5, 128-132 [in Ukrainian].

Kupreichenko, A. B. (2008). Psikhologiia doveriia i nedoveriia [Psychology of trust and distrust]. Moskva : Izd-vo «Institut psikhologii RAN》 [in Russian].

Kupreichenko, A. B. (2011). Psikhologiia doveriia i nedoveriia lichnosti reklame [Psychology of trust and mistrust of personality in advertising]. Praktychna psykholohiia ta sotsialna robota - Practical Psychology and Social Work, 11, 5-15 [in Russian].

Lysenko, D. P. (2018). Dovira yak sotsialno-psykholohichnyi fenomen [Trust as a socio-psychological phenomenon]. Teoriia i praktyka suchasnoi psykholohii - Theory and practice of modern psychology, 3, 123-126 [in Ukrainian].

Miasoid, P. (2016). Tvorchist V. A. Romentsia i problema liudyny u psykholohii [Creativity of V. A. Romenets and the problem of man in psychology]. Psykholohiia i suspilstvo - Psychology and society, 2, 48-72 [in Ukrainian].

Holovakha, E., Kostenko, N., \& Makieieva, S. (Eds.) (2014). Obshchestvo bez doveriia [Society without trust]. Kiev : Institut sotsiologii NAN Ukrainy [in Russian].

(C) Shtepa Olena

DOI (article): https://doi.org/10.32626/2227-6246.2020-50.352-374 
Pushkarev, Yu. I. (2012). Lichnost kak subiekt adaptatsii $i$ subiekt interpretatsii: sistemno-germenevticheskii podkhod $k$ izucheniiu lichnosti [Personality as a subject of adaptation and a subject of interpretation: a system-hermeneutic approach to the study of personality]. Belgorod : ID «Belgorod» [in Russian].

Chepelieva, N. V., Smulson, M. L., Zazymko, O. V., Hutsol, S. Yu., \& others (2016). Samoproektuvannia osobystosti u dyskursyvnomu prostori [Self-design of personality in discursive space]. N. V. Chepelieva (Ed.). Kyiv : Pedahohichna dumka [in Ukrainian].

Sanotska, N. Ya. (2017). Kontury postpravdy v informatsiinomu suspilstvi [The contours of the post-truth in the information society]. Aktualni problemy filosofii ta sotsiolohii - Current issues of philosophy and sociology, (pp. 108-111) [in Ukrainian].

Fukuiama, F. (2004). Doveriie: sotsialnyie dobrodeteli i put $k$ protsvetaniiu [Trust: social virtues and the way to prosperity]. Moskva : $\mathrm{OOO}$ «Izdatelstvo ACT»: ZAO NPP «Ermak». Retrieved from http://yanko. lib.ru [in Russian].

Khazova, S. A. (2014). Mentalnyie resursy subiekta v raznyie vozrastnyie periody [The mental resources of the subject in different age periods]. Doctor's thesis. Kostroma : Kostromskoi gosudarstvennyi universitet imeni N. A. Nekrasova. Retrieved from https://cyberleninka.ru/article/n/mentalnye-resursy-subekta-priroda-funktsiidinamika [in Russian].

Shevchenko, S. V. (2015). Suchasni uiavlennia pro fenomen doviry do sebe [Modern ideas about the phenomenon of self-confidence]. Visnyk pisliadyplomnoi osvity - Bulletin of postgraduate education, 15, 264275. Retrieved from http://nbuv.gov.ua/UJRN/Vpo_2015_15_26 [in Ukrainian].

Shtepa, O. S. (2019a). Znachennia psykhologichnykh resursiv v aktualizatsii smyslovykh konstruktiv [The value of psychological resources in the actualization of semantic constructs]. Problemy suchasnoi psykholohii - Problems of Modern Psychology. Collection of research papers of Kamianets-Podilskyi National Ivan Ohiienko University, G. S. Kostiuk Institute of Psychology of the National Academy of Educational Sciences of Ukraine, 45, 429-450. Kamianets-Podilskyi : Aksioma. DOI 10.32626/2227-6246.2019-45 [in Ukrainian].

Shtepa, O. S. (2019b). Resursna ta motyvatsiina aktualizatsiia chuttia samoefektyvnosti [Resource and motivational actualization of the sense of self-efficacy]. Zdoroviia u multydystsyplinarnomu dyskursi-Health in a multidisciplinary discourse: Proceedings of the International Scientific and Practical Conference, (pp. 91-94). Lviv : Ukrainskyi katolytskyi universytet [in Ukrainian].

(C) Shtepa Olena

DOI (article): https://doi.org/10.32626/2227-6246.2020-50.352-374 
Shtepa, O. S. (2020). Resursna nasychenist osobystosti [Resource richness of personality]. Problemy suchasnoi psykholohii-Problems of Modern Psychology. Collection of research papers of Kamianets-Podilskyi National Ivan Ohiienko University, G. S. Kostiuk Institute of Psychology of the National Academy of Educational Sciences of Ukraine, 47, 231-252. Kamianets-Podilskyi : TOV «Drukarnia «Ruta». DOI 10.32626/2227-6246.2020-47.231-252 [in Ukrainian].

Peterson, C., \& Seligman, M. (2004). Character Strengths and Virtues. A Handbook and Classification. OXFORD UNIVERSITY PRESS. Retrieved from http://ldysinger.stjohnsem.edu/\% 40books1/Peterson_ Character_Strengths/character-strengths-and-virtues.pdf.

Zanini, M., \& Migueles, C. (2013). Trust as an element of informal coordination and its relationshipwith organizational performance. EconomiA, 14, 77-87. Retrieved from http://dx.doi.org/10.1016/j.econ. 2013.08.005.

\section{Штепа Олена. Психологічні ресурси особистісної конфіденції: можли- вості довіри людини до себе й інших}

\section{АНОТАЦІЯ}

Мета статmі - з'ясувати ресурси особистісної конфріденції в емпіричний спосіб.

Методи. Застосовано психологічне опитування з використанням таких методик, як опитувальник персональної ресурсності, опитувальник психологічної ресурсності, тест-опитувальник діагностики показників екзистенціальних ресурсів, анкета чеснот і сил характеру, опитувальник стратегій подолання кризового стану, опитувальник психологічного благополуччя, шкала когерентності, методика визначення (ін) толерантності до невизначеності, методики оцінки та прогнозування психологічного розвитку ситуацій міжособистісної взаємодії, опитувальник рефлексивності, методика довіри / недовіри особистості світу, іншим людям, собі. Застосовано такі методи математико-статистичного аналізу, як Tests of Normality, багатофакторний аналіз, кластерний аналіз методом к-середніх, класифікаційний аналіз, порівняльний аналіз, дискримінантний аналіз. Емпіричне дослідження реалізовано за моделлю Нельсона, оскільки для визначення ресурсів особистісної конфріденції було задано умови, а саме: рівень довіри особи до себе, рівень довіри особи до інших, рівень системної рефлексії, визначеність ресурсного контенту.

(c) Shtepa Olena

DOI (article): https://doi.org/10.32626/2227-6246.2020-50.352-374 
DOI: https://doi.org/10.32626/2227-6246.2020-50 2020. випуск 50

Результати дослідження. Доведено, що пошук людиною недоліків у себе й інших є критерієм їі готовності не довіряти як собі, так і іншим. Предикторами уможливлення конфіденції $\epsilon$ психологічні ресурси роботи над собою, відповідальності, допомоги іншим, що реалізуються через ресурси як «сили характеру» (відкритість новому досвіду, лідерство, здатність вибачати, чуйність). За результатами емпіричного дослідження саме лідерство як уміння надихати й організовувати себе й інших $\epsilon$ головним чинником і предиктором довіри особи до себе й інших людей.

Висновки. Головними ресурсами уможливлення конфріденції $\epsilon$ рефрлексовані ресурси, до яких належать психологічні ресурси і ресурси як «сили характеру». Відтак, є підстави визначити «ресурсами зцілення» психологічні ресурси роботи над собою, (розділеної) відповідальності, доброти до інших і допомоги їм, що інтерпретують, a, отже, дають змогу концептуалізувати суб'єкту активність, тобто умонливлюють саморозуміння особистості; а також такі "сили характеру», як відкритість новому досвіду, лідерство, здатність вибачати, чуйність, що дають змогу аргументувати здобуте розуміння.

Ключові слова: психологічні ресурси, особистісна конфріденція, "ресурси зцілення», довіра людини до себе, довіра людини до інших.

\section{Штепа Елена. Психологические ресурсы конфиденции: возможности доверия человека себе и другим}

\section{АННОТАЦИЯ}

Цель статьи - определить ресурсы личностной конфиденции эмпирическим способом.

Методы. Применен психологический опрос с использованием опросника персональной ресурсности, опросника психологической ресурсности, тест-опросника диагностики показателей экзистенциальных ресурсов, опросника добродетелей и сил характера, опросника стратегий преодоления кризисного состояния, опросника психологического благополучия, шкалы когерентности, методики определения толерантности к неопределенности, методики оценки и прогнозирования развития ситуаций межличностного взаимодействия, опросника рефлексивности, методики доверия / недоверия личности миру, другим, себе. Использованы такие методы математико-статистического анализа, как Tests of Normality, многофакторный анализ, кластерный анализ, классификационный ана-

(c) Shtepa Olena

DOI (article): https://doi.org/10.32626/2227-6246.2020-50.352-374 
лиз методом k-средних, сравнительный анализ, дискриминантный анализ. Эмпирическое исследование реализовано по модели Нельсона, поскольку для определения ресурсов личностной конфиденции были заданы условия, а именно: уровень доверия человека себе, уровень доверия человека другим, уровень системной рефлексии, определенность ресурсного контента.

Результаты исследования. Обосновано, что поиск человеком недостатков у себя и других является критерием его готовности не доверять как себе, так и другим. Предикторами воплощения конфиденции в отношении человека к себе и другим являются психологические ресурсы работы над собой, ответственности, помощи другим, реализующиеся через ресурсы как "силы характера» (открытость новому опыту, лидерство, способность прощать, добросердечность). По результатам эмпирического исследования именно лидерство как умение вдохновлять и организовывать себя и других является главным фактором и предиктором доверия человека себе и другим людям.

Выводы. Главными ресурсами воплощения конфиденции являются ресрлексируемые ресурсы, к которым относятся психологические ресурсы и ресурсы как "силы характера». Результаты исследования дают основания считать "ресурсами исцеления» психологические ресурсы работы над собой, (разделенную) ответственность, доброту к другим и помощь им, которые интерпретируют и, соответственно, дают возможность концептуализировать субъектную активность, то есть реализовать самопонимание личности; а также такие «силы характера», как открытость новому опыту, лидерство, способность прощать, добросердечность, дающие возможность аргументировать полученное понимание.

Ключевые слова: психологические ресурсы, личностная конфиденция, "ресурсы исцеления», доверие человека себе, доверие человека другим.

Original manuscript received June 01, 2020 Revised manuscript accepted July 08, 2020 